\title{
ANALISIS KEBUTUHAN PENGEMBANGAN MEDIA PEMBELAJARAN GEOMETRI BERMUATAN PENDIDIKAN KARAKTER MENGGUNAKAN MACROMEDIA FLASH 8 BERBASIS ANDROID
}

\author{
Stepanus Daling ${ }^{1}$, Mohamad Rif'at ${ }^{1}$, Adriana Nada Beta ${ }^{2}$, Hodiyanto² \\ Rahman Haryadi ${ }^{2}$ \\ ${ }^{1}$ Program Studi Pasca Sarjana Pendidikan Matematika FKIP Untan \\ Pontianak \\ ${ }^{2}$ Program Studi Pendidikan Matematika IKIP-PGRI Pontianak
}

Email Korespondensi : step.dlg29@gmail.com

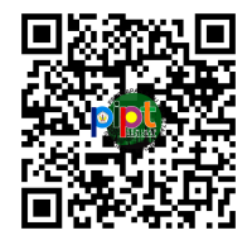

$\underline{10.26418 / \text { pipt. } 2021.3}$

\begin{abstract}
Abstrak
Penelitian ini bertujuan untuk mengetahui kebutuhan media pembelajaran yang akan dikembangkan menggunakan aplikasi Macromedia Flash 8 pada pokok bahasan Geometri Dimensi Tiga. Penelitian ini merupakan penelitian awal yang termasuk di dalam tahap Pendefinisian (Define) dalam prosedur R \& D model 4D (four-D) yang telah dimodifikasi menjadi 3D meliputi tiga tahapan yaitu: pendefinisian (define), perancangan (design) dan pengembangan (develop). Penelitian ini hanya terbatas pada tahap Define. Teknik pengumpulan data dilakukan dengan cara observasi dan wawancara terhadap Guru dan Peserta Didik kelas X SMA Wisuda Pontianak. Hasil penelitian ini menunjukkan bahwa dalam pembelajaran geometri dibutuhkan media pembelajaran berbentuk Macromedia Flash 8 berbasis android yang bermuatan nilai-nilai pendidikan karakter pada peserta didik.
\end{abstract}

Kata kunci: Macromedia Flash 8, Pendidikan Karakter, Geometri

\section{PENDAHULUAN}

Perkembangan ilmu pengetahuan dan teknologi yang semakin pesat semakin menuntut kita untuk terus mengembangkan wawasan dan kemampuan di berbagai bidang. Keadaan ini ditandai dengan adanya berbagai penemuan-penemuan, terutama di bidang keterampilan dari berbagai ilmu pengetahuan dan teknologi. Tidak dapat dipungkiri bahwa dalam ruang lingkup pendidikan juga tidak lepas dari pengaruh perkembangan teknologi.

Alat-alat teknologi yang seringkali dimanfaatkan dalam bidang pendidikan, misalnya kertas sebagai media cetak, mesin cetak, radio, TV, komputer, proyektor dan lain-lain sebagainya. Alat-alat teknologi yang digunakan dalam pendidikan tersebut mampu mengubah pandangan, pola pikiran manusia, mengubah sistem kerja, dan cara hidup manusia.

Selain itu, dalam proses pembelajaran, alat-alat teknologi dapat mengubah peranan guru dari penyampai pengetahuan, sebagai sumber utama informasi, dan ahli dalam materi menjadi fasilitator bagi peserta didik. Dalam bidang pendidikan, pemanfaatan komputer tidak hanya digunakan sebagai alat untuk mempermudah pengadministrasian melainkan juga dapat membantu guru dalam berinovasi untuk membuat dan mengembangkan media pembelajaran. Media pembelajaran yang bisa dikembangkan misalnya LKPD, buku saku, booklet, Power Point, Video Pembelajaran dan Macromedia Flash 8.

Menurut Sadiman, dkk. (2012), media adalah segala sesuatu yang dapat digunakan untuk menyalurkan pesan dari pengirim ke penerima sehingga dapat merangsang pikiran, perasaan, perhatian dan minat siswa sehingga proses belajar dapat tercapai secara maksimal. Dengan adanya media dapat memancing respon peserta didik dalam proses belajar mengajar yang dilaksanakan sehingga memunculkan timbal balik yang positif antara informasi yang disampaikan oleh guru kepada peserta didik.

Media yang bisa digunakan dalam pembelajaran sangat beragam, satu diantaranya adalah Macromedia Flash 8. 
Macromedia Flash 8 adalah salah satu software yang mempunyai kelebihan yakni mampu menampilkan animasi grafis yang bervariasi sehingga lebih komunikatif dibandingkan media lainnya. Macromedia Flash 8 juga mampu mencairkan suasana belajar jika diberikan gambar dan tambahan audio sehingga lebih mudah dipahami dan diingat oleh peserta didik.

Menurut Masykur, dkk. (2017) Macromedia flash 8 merupakan media yang memiliki keunggulan sehingga mempermudah dalam menyiapkan bahan ajar menjadikan bahan ajar yang bersifat abstrak menjadi lebih real dan meningkatkan konsep pemahaman siswa. Hal ini diperkuat oleh Hodianto, dkk. (2020) yang mengemukakan bahwa Macromedia flash 8 merupakan media pembelajaran yang bisa memuat bahan ajar agar tujuan pembelajaran bisa tercapai.

Dalam mengembangkan media pembelajaran Macromedia flash 8 tentu perlu diperhatikan dan disesuaikan dengan permasalahan yang dialami oleh guru dan peserta didik. Berdasarkan kondisi seperti sekarang ini dalam masa pandemi covid19 saat pembelajaran dilaksanakan secara during yang mengakibatkan banyak sekali masalah bagi guru dan peserta didik. Menurut Rahman, S.R. (2020) mengungkapkan bahwa salah satu bentuk alternative yang dapat dilaksanakan selama masa darurat Covid-19 adalah pembelajaran secara online.

Dari berbagai kebijakan pemerintah agar mematuhi protocol kesehatan tentu harus dilaksanakan sebaik-baiknya. Hal tersebut secara tidak langsung akan mempengaruhi bagaimana sistem pembelajaran akan dilaksanakan. Sebelum pandemic covid19 kegiatan pembelajaran dilaksanakan secara luring dimana guru dan peserta didik bertatap muka langsung.

Di dalam kelas, guru bisa mengontrol setiap tindakan dan tugas-tugas yang akan dilakukan oleh peserta didik, pembelajaran di dalam kelas untuk saling berdiskusi yang menumbuhkan rasa semangat kerjasama, kejujuran, rasa ingin tahu ketika peserta didik mengajukan pertanyaan terkait materi yang belum dipahami dan dalam belajar jelas peserta didik dan guru tidak bermasalah dengan jaringan.

Sementara saat ini, kegiatan-kegiatan tersebut memang masih bisa dilakukan meskipun secara during akan tetapi terdapat berbagai keterbatasan yang menimbulkan masalah baru yakni kemerosotan nilai-nilai karakter pada peserta didik disebabkan berbagai faktor salah satunya penggunaan teknologi. Teknologi yang seringkali digunakan dalam pembelajaran online salah satunya adalah smartphone. Penggunaan smartphone sangat sensitif sekali, dilihat dari sisi positifnya memang sangat membantu dalam mengakses berbagai informasi tetapi tidak menutup kemungkinan, smartphone juga bisa mengarahkan karakter peserta didik pada hal yang membuat moral dan mentalitasnya menurun.

Seperti diungkapkan oleh Pantu \& Luneto, (2014) akibat dari kemajuan teknologi menyebabkan kemerosotan moralitas pada kalangan remaja sehingga perlu diberlakukan pendidikan karakter sejak dini. Hal ini memang tidak bisa dihindari, karena tidak semua orang siap khususnya guru dan peserta didik dalam menghadapi perubahan sistem pembelajaran yang berlaku saat ini.

Maka dari itu, dalam pelaksanaan pembelajaran secara during sebaiknya tidak lupa selalu menerapkan nilai-nilai pendidikan karakter. Salah satu cara yang bisa dilakukan adalah dengan upaya mengembangkan media pembelajaran Macromedia Flash 8 yang menyajikan ide konsep yang ada pada materi matematika yang akan disampaikan dengan muatan nilai-nilai pendidikan karakter tentu akan berdampak baik pada perkembangan karakter peserta didik. Salah satu materi pelajaran matematika adalah Geometri Dimensi Tiga. Geometri Dimensi Tiga merupakan bagian dari ilmu matematika yang membahas tentang bentuk dan ukuran dari suatu obyek yang memiliki keteraturan tertentu. 
Tujuan dari penelitian ini adalah untuk mengetahui kebutuhan guru dan peserta didik terhadap media pembelajaran menggunakan Macromedia Flash 8 pada pokok bahasan geometri bermuatan nilainilai karakter bagi peserta didik.

\section{METODOLOGI}

Penelitian ini merupakan penelitian awal yang termasuk di dalam tahap pra pengembangan dalam prosedur penelitian dan pengembangan $(\mathrm{R} \& \mathrm{D})$ model $4 \mathrm{D}$ (four-D) yang telah dimodifikasi menjadi 3D meliputi tiga tahapan yaitu: pendefinisian (define), perancangan (design) dan pengembangan (develop). Penelitian ini hanya terbatas pada tahap Define yang bersumber dari data hasil pra riset di lapangan serta kajian terhadap literaturliteratur yang relevan dengan penelitian ini. Penelitian dilakukan di SMA Wisuda Pontianak. Subjek dari penelitian ini terdiri dari Guru mata pelajaran matematika dan peserta didik yang dipilih secara acak. Adapun teknik pengumpulan data dalam penelitian ini menggunakan observasi dan wawancara. Kemudian data yang diperoleh dianalisis secara deskriptif kualitatif.

\section{HASIL DAN PEMBAHASAN}

Penelitian dilakukan di SMA Wisuda Pontianak, hasil dari penelitian ini mengungkap analisis kebutuhan guru dan peserta didik terhadap media pembelajaran yang akan dikembangkan. Teknik pengumpulan data yang digunakan dalam penelitian ini adalah observasi dan wawancara. Observasi dilakukan di SMA Wisuda Pontianak. Berdasarkan observasi selama proses pembelajaran berlangsung diperoleh data sebagaimana tercantum pada Tabel 1 berikut.

Tabel 1. Hasil Observasi

\begin{tabular}{|l|l|lll|}
\hline NO. & Kegiatan & Analisis & \\
\hline 1 & $\begin{array}{l}\text { Pengamatan } \\
\text { terhadap guru }\end{array}$ & $\begin{array}{l}\text { Guru mengajar } \\
\text { metode }\end{array}$ ceramah, & diskusi \\
\hline
\end{tabular}

\begin{tabular}{|c|c|c|}
\hline & & dan berkelompok \\
\hline & & $\begin{array}{l}\text { Guru menggunakan media } \\
\text { LKPD, Power Point, Video } \\
\text { Pembelajaran, Google Meet } \\
\text { dan Zoom }\end{array}$ \\
\hline & & $\begin{array}{lr}\text { Guru belum } & \text { pernah } \\
\text { mengembangkan } & \text { media } \\
\text { pembelajaran } & \text { melalui } \\
\text { macromedia flash } 8 & \\
\end{array}$ \\
\hline 2 & $\begin{array}{l}\text { Pengamatan } \\
\text { terhadap siswa }\end{array}$ & $\begin{array}{l}\text { Peserta didik menggunakan } \\
\text { smartphone (android) untuk } \\
\text { belajar }\end{array}$ \\
\hline & & $\begin{array}{l}\text { Peserta didik belajar } \\
\text { menggunakan buku paket }\end{array}$ \\
\hline & & $\begin{array}{l}\text { Peserta didik kurang } \\
\text { memperhatikan } \\
\text { pembelajaran saat di kelas } \\
\text { ketika belum pandemic } \\
\text { covid19 }\end{array}$ \\
\hline 3 & $\begin{array}{l}\text { Pengamatan } \\
\text { terhadap } \\
\text { media }\end{array}$ & $\begin{array}{l}\text { Tersedia buku paket, LKPD, } \\
\text { computer, dan Proyektor di } \\
\text { sekolah }\end{array}$ \\
\hline & $\begin{array}{l}\text { pembelajaran } \\
\text { yang } \\
\text { digunakan }\end{array}$ & $\begin{array}{l}\text { Google meet dan Zoom } \\
\text { sering digunakan dalam } \\
\text { kegiatan pembelajaran. }\end{array}$ \\
\hline 4 & $\begin{array}{l}\text { Pengamatan } \\
\text { hasil belajar } \\
\text { peserta didik }\end{array}$ & $\begin{array}{l}\text { Hanya } 30 \% \text { dari banyak } \\
\text { peserta didik yang mencapai } \\
\text { KKM secara murni ketika } \\
\text { mengikuti tes. }\end{array}$ \\
\hline
\end{tabular}

Wawancara dilakukan terhadap guru dan beberapa peserta didik kelas X SMA Wisuda Pontianak. Adapun rangkuman hasil wawancara yang diperoleh adalah: Proses pembelajaran matematika pokok bahasan geometri hanya menggunakan buku pelajaran, video pembelajaran dan power point saja ketika pembelajaran tatap muka berlangsung, pembelajaran dilakukan secara daring karena pandemi Covid 19 menggunakan aplikasi zoom, google meet dan whatshapp, guru belum pernah menggunakan media pembelajaran berbentuk Macromedia Flash 8 dalam pembelajaran matematika, guru tidak bisa membuat media pembelajaran berbentuk Macromedia Flash 8, dengan sistem pembelajaran secara daring, guru hanya bisa menyampaikan materi saja tetapi penerapan pendidikan karakter tidak sepenuhnya bisa dilakukan, guru menyatakan yang menjadi kendala dalam penyampaian materi adalah keterbatasan waktu dalam penggunaan aplikasi terutama pada saat menggunakan 
zoom meeting, guru tidak bisa mengontrol semua peserta didik secara langsung saat kegiatan pembelajaran dilakukan secara daring.

Kemudian dari hasil pengamatan Guru saat pembelajaran secara daring menerangkan bahwa Peserta didik tidak sepenuhnya terfokus pada materi yang disampaikan Guru, ada beberapa peserta didik yang terkendala jaringan sehingga tidak bisa mengikuti kegiatan pembelajaran yang dilakukan via zoom meeting dan mengakibatkan ketinggalan materi pelajaran, dengan media yang digunakan saat ini, peserta didik tidak bisa mengulangi materi sehingga mengakibatkan sulitnya bagi peserta didik dalam mendalami materi yang disampaikan, pengumpulan tugas menggunakan aplikasi google meet yang mana masih banyak peserta didik tidak bisa menggunakanya, peserta didik terkadang tidak tepat waktu dan ada yang tidak mengumpulkan tugas dengan berbagai macam alasan, hasil tugas maupun test dari peserta didik seringkali sama, peserta didik tidak antusias untuk mengetahui materi pembelajaran, peserta didik kurang memahami konsep dalam pokok bahasan geometri khususnya materi Garis dan Sudut secara analitis.

\section{Pembahasan}

Dapat kita lihat bahwa nilai-nilai pendidikan karakter yang sangat penting adalah sikap disiplin, kejujuran, rasa ingin tahu, toleransi, mandiri, kerja keras, religius dan lain sebagainya. Apabila nilai - nilai tersebut tidak dibiasakan dalam pembelajaran maka secara otomatis dapat membiasakan karakter peserta didik ke arah yang negative. Menurut Nasrullah (2015: 483) menerangkan bahwa pendidikan karakter sebagai pendidikan bersama yang harus dilakukan secara terintegrasidan koheren oleh semua pihak yang terlibat. Artinya semua pihak secara bersama-sama membangun dan menerapkan nilai-nilai dari pendidikan karakter agar berjalan dengan baik.
Dalam penerapan nilai-nilai pendidikan karakter tentu perlunya suatu strategi atau perencanaan yang dapat mendukung terwujudnya nilai-nilai dari pendidikan karakter secara maksimal. Menurut Irawatie, Israwahyuni \& Setyawati, (2019: 36) pada dasarnya untuk melaksanakan pendidikan tidak hanya dilakukan secara parsial dan instan. Penerapan pendidikan karakter harus dilaksanakan dengan penuh rancangan dan perencanaan secara bertahap, dan harus disesuaikan dengan kondisi di lingkungan sekitar.

Dalam lingkungan pendidikan, perencanaan yang perlu dilakukan bisa dimulai dari pembiasaan kepada peserta didik akan nilai-nilai pendidikan karakter yang lebih menekankan pada perubahan karakter dan kebiasaaannya yang mengarahkan kepada terwujudnya manusia yang berkarakter dan bermoral sehingga berguna bagi Bangsa dan Negara.

Kegiatan pembelajaran yang terjadi saat pandemi ini memunculkan suatu kebiasaan yang sangatlah berdampak negatif bagi karakter peserta didik. Dari pengamatan guru juga ketika mengajar secara daring, peserta didik tidak bisa diajak focus sepenuhnya untuk memperhatikan materi pembelajaran yang sedang dijelaskan. Apalagi jika peserta didik terkendala dengan jaringan ketika mengikuti pembelajaran, seringkali mereka tiba-tiba keluar dari kegiatan pembelajaran dan bahkan ada peserta didik yang sengaja ikut membuka link pembelajaran tapi melakukan hal lain, hal ini tentu sangatlah menghambat ketercapaian tujuan pembelajaran seperti yang diharapkan.

Permasalahan - permasalahan tersebut dapat dijadikan suatu inovasi baru, dilihat dari bagaimana permasalahan-permasalahan yang dialami guru dan peserta didik pada saat melakukan pembelajaran secara daring. Artinya masalah yang ada bukanlah suatu hambatan untuk terus melakukan pembelajaran secara daring mengingat kondisi saat ini harus melakukan protocol kesehatan tetapi masalah tersebut perlu ditindaklanjuti dengan mencari suatu solusi 
yang dapat membantu terlaksananya pembelajaran dengan baik dan lancar dengan tidak lupa tetap menerapkan nilai-nilai dari pendidikan karakter kepada peserta didik.

Macromedia Flash 8 merupakan aplikasi yang dapat digunakan untuk membuat salah satu media pembelajaran berbasis android. Pengembangan media pembelajaran berbantuan Macromedia Flash 8 dapat dijadikan solusi dalam keterbatasan media pembelajaran yang tersedia dan dapat membantu meningkatkan pemahaman akan nilai-nilai pendidikan karakter kepada peserta didik karena dikembangkan dengan muatan pendidikan karakter dalam penyajiannya. Dengan muatan pendidikan karakter diharapkan peserta didik akan aktif dan antusias dalam proses pembelajaran secara baik dan berkarakter.

Dari hasil penelitian ini, selanjutnya perlu dikembangkannya media pembelajaran matematika menggunakan Macromedia Flash 8 untuk pokok bahasan geometri dimensi tiga pada penelitian selanjutnya.

\section{KESIMPULAN}

Berdasarkan kegiatan analisis data hasil penelitian dan pembahasan yang telah dilakukan penulis menyimpulkan bahwa pada proses pembelajaran Geometri Dimensi Tiga dibutuhkan media pembelajaran yang dapat melibatkan peserta didik untuk aktif ambil bagian dalam pembelajaran matematika yang dilaksanakan baik secara daring maupun secara luring tanpa melupakan nilai-nilai pendidikan karakter. Media pembelajaran tersebut dibuat menggunakan Macromedia Flash 8, sehingga dapat dikembangkan dengan tampilan yang menarik dan dapat meningkatkan motivasi dan kreativitas peserta didik.

Hasil dari penelitian ini diharapkan dapat memberikan informasi awal mengenai media pembelajaran yang akan dikembangkan sehingga bermanfaat sebagai sumber pendukung dalam kegiatan pembelajaran dan penelitian selanjutnya sebagai tindak lanjut penelitian ini

\section{UCAPAN TERIMA KASIH}

Dalam penulisan artikel penelitian ini, penulis tidak lupa mengucapkan syukur kepada Tuhan Yang Maha esa atas berkatnya sehingga penulisan artikel ini bisa selesai dan ucapan terima kasih kepada: Bpk. Dr. Mohamad. Rif'at, M.Pd, Bpk. Hodiyanto,M.Pd, Bpk. Rahman Haryadi yang selalu memberikan motivasi dan masukkan yang sangat berarti kepada penulis, Sdri. Adriana Nada Beta ikut serta membantu penulisan artikel ini.

\section{DAFTAR PUSTAKA}

Hodiyanto, Darma, Y., Syarif S Putra, dan R., Studi Pendidikan Matematika, P., $\&$ PGRI (2020). Pengembangan Media Pembelajaran Berbasis Macromedia Flash Bermuatan Problem Posing terhadap Kemampuan Pemecahan Masalah Matematis Development of Macromedia Flash-Based Learning Media with Problem Posing to Mathematical Problem Solving Ability. Jurnal Pendidikan Matematika, 9(2), 323-334.

Irawatie, A., Israwahyuni, I., \& Setyawati, M. E. (2019). Education Learning Development of Character Education-Based State Defense. International Jurnal of Multikultural and Multireligious Understanding, 6(8), 27-42.

Masykur, R., Nofrizal, N., \& Syazali, M. (2017). Pengembangan Media Pembelajaran Matematika dengan Macromedia Flash. Al-Jabar : Jurnal Pendidikan Matematika, 8(2), 177.

Nasrullah. (2015). Pembentukan Karakter Siswa Melalui Pendidikan Agama Islam. Jurnal Salam, 18(1), 67-82.

Pantu, A., \& Luneto, B. (2014). Pendidikan Karakter Dan Bahasa. Jurnal Pendidikan, 14(1). 
Rahman, S. R. (2020). Pembelajaran Online di Tengah Pandemi Covid-19. Jurnal of Educational Science (IJES), 02(02), 81-89.

Sadiman, Sukadi, A., Rahardjo, R., Haryono, A., dan Rahardjito. (2012). Media Pendidikan: Pengertian, Pengembangan, dan Pemanfaatannya. Depok: Rajawali press. 